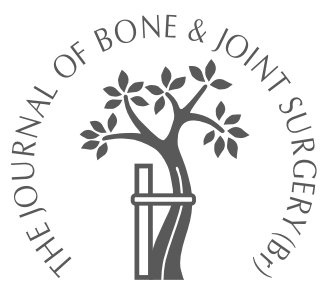

M. A. Hashmi, P. Norman, M. Saleh

From the University of Sheffield, England

M. A. Hashmi, MB BS, MSc, FRCS, Specialist Registrar in Orthopaedics Freeman Hospital,

Newcastle-upon-Tyne, UK.

P. Norman, FRC Path Consultant Microbiologist Microbiology Department M. Saleh, MSc, FRCS,

Professor of Trauma and

Orthopaedics

Clinical Sciences Section Northern General Hospital, Herries Road, Sheffield S5 7AU, UK.

Correspondence should be sent to Mr M. A. Hashmi at 11 Davenport Drive, Gosforth, Newcastle-upon-Tyne NE3 $5 A E, U K$.

(C)2004 British Editorial Society of Bone and

Joint Surgery

doi:10.1302/0301-620X.86B2. $14011 \$ 2.00$

$J$ Bone Joint Surg [Br] 2004;86-B:269-75.

Received 14 November 2002;

Accepted after revision

16 July 2003

\title{
The management of chronic osteomyelitis using the Lautenbach method
}

We describe our medium-term results for the management of chronic osteomyelitis in long bones using the Lautenbach procedure. Seventeen consecutive patients (18 segments) were treated prospectively. Osteomyelitis had been present for a mean of 12.5 years (1 to 31). A discharging sinus was present in all cases. Nine of the associated fractures had failed to unite and a further two needed correction of malunion. The Lautenbach procedure involves debridement, intramedullary reaming and the insertion of double-lumen tubes to establish both a local antibiotic delivery system and cavity analysis for volume and culture. The end-point of treatment is when the irrigate produces three consecutive clear cultures with improvement in the blood indices and obliteration of the cavity volume.

The mean length of treatment was 27 days (14 to 48). One patient required a second procedure and another local debridement for recurrence of the infection. Two patients had Papineau grafting because of cortical defects. All the patients have subsequently remained free from infection. After treatment $\mathbf{1 1}$ had internal or external fixation for treatment of non- or malunion or a joint replacement, including two successful limb-lengthening procedures. Two further patients, while cured of infection, underwent amputation for other reasons. The mean length of follow-up was 75 months.

This procedure allows precise control over the osteomyelitis until objective assessment suggests that infection has been cleared and the cavity obliterated.

We recommend this procedure for long-standing complex cases in which basic techniques using debridement and antibiotics have failed.

Chronic osteomyelitis remains one of the most challenging problems in orthopaedic surgery. ${ }^{1-6}$ It commonly occurs after trauma involving either an open fracture or internal fixation. ${ }^{1}$ The event which heralds the transition from acute to chronic osteomyelitis is bacterial attachment to a functionally inert non-resorbable substratum, either a sequestrum or a foreign body. ${ }^{7}$

In chronic osteomyelitis infected, dead bone lies within a compromised soft-tissue envelope. ${ }^{8}$ Many regimes have been proposed for the treatment of chronic osteomyelitis including antibiotics, ${ }^{9-12}$ debridement and en-bloc excision, ${ }^{1,13}$ staged management, ${ }^{14}$ closed irrigation and suction drainage ${ }^{15-21}$ initially described by Smith-Petersen et al ${ }^{20}$ in 1945 , open bone grafting $2,22-28$ and muscle transfer. ${ }^{14,29-31}$

Weber and Lautenbach ${ }^{21}$ developed a technique and reported its use in a series of patients with infected total hip arthroplasties. The procedure involved radical debridement and excision of all avascular scarred and infected tissue, followed by debridement of the infected endosteum, reaming and the insertion of a local antibiotic delivery system. In contrast to other methods of closed suction drainage the system did not rely on rapid fluid flow and mechanical washing but on the local delivery of high concentrations of appropriate antibiotics. The ability to drain off effluent allowed precise monitoring of microbiological changes, appropriate modification of antibiotic therapy and gradual obliteration of the dead space.

We have prospectively studied a consecutive cohort of 17 patients with diffuse chronic osteomyelitis treated by the techique of Weber and Lautenbach and describe the results at a mean follow-up of 75 months.

\section{Patients and Methods}

We first used this treatment in November 1995 and the initial procedure and the post-operative care were supervised by Lautenbach.

There were 17 men with a mean age of 37 years (17 to 53; median 37). Eleven were smokers. According to the classification of 
Table I. The pre-operative blood indices

\begin{tabular}{lccc}
\hline Test & Mean & Median & Range \\
\hline White cell count $\left(10^{9} / \mathrm{l}\right)$ & 9.05 & 8.0 & 4 to 21 \\
ESR $(\mathrm{ml} / \mathrm{hr})$ & 72.33 & 76.5 & 6 to 180 \\
C-reactive protein $(\mathrm{mg} / \mathrm{dl})$ & 47.5 & 21.0 & 5 to 168 \\
Haemoglobin $(\mathrm{g} / \mathrm{dl})$ & 12.9 & 13.0 & 10 to 15 \\
\hline
\end{tabular}

Cierny and Mader $^{8}$ and Cierny, ${ }^{32} 16$ were type-A and one type-B hosts with diffuse chronic osteomyelitis (65\% type IV and $35 \%$ type III).

The aetiology was post-traumatic in all cases and included 15 high-energy and two intermediate-energy injuries. The femur was involved in nine and the tibia in eight. The original fractures were open in 13 cases, and closed in five. The initial management was by external fixation in three patients, intramedullary nailing in seven and plate osteosynthesis in seven. These patients had received conventional surgical debridement and antibiotic treatment at their primary hospitals. The mean time from injury was 12.8 years ( 1 to 31 ; median 15 ). When first seen at our centre all had local signs of infection including a discharging sinus. Nine had an ununited fracture and deformity requiring realignment or lengthening. In the patients in whom the fracture had united, two had a malunion needing corrective surgery. All underwent investigation including, a full blood count, measurement of the ESR and C-reactive protein and a microbiological profile. Plain radiography and a bone scan were performed on every patient. The bone scans were used to determine the extent of the infection and the presence or absence of a 'sump infection' which occurs in the distal femur or tibia as a result of dependant drainage from the primary site. Raised uptake of isotope is seen in the distal metaphysis discrete from either the primary focus or the joint in all phases of the scan. The investigations were then reviewed by an experienced orthopaedic radiologist and further investigations including tomography, CT, MRI, or indium-labelled white cell scanning performed depending on the clinical need. The diagnosis was made on the basis of clinical presentation and imaging, and confirmed bacteriologically and histologically from specimens obtained during the operation. The pre-operative blood indices are shown in Table I and Figure 1.

Operative technique. The anaesthetised patient is placed supine on a radiolucent operating table in a clean-air theatre. An image intensifier is available. Antibiotics are not given until adequate superficial and deep specimens have been taken for microbiological assessment. The approach for direct debridement of the affected segment of bone depends upon the location of the sinuses and where breeches in the cortex and sequestra are seen on the radiological studies. Scarred ischaemic or necrotic subcutaneous tissue, deep fascia and muscle are excised, after frequent referral to the imaging, and obvious sequestra and dead bone are removed. When nonunion is present, necrotic

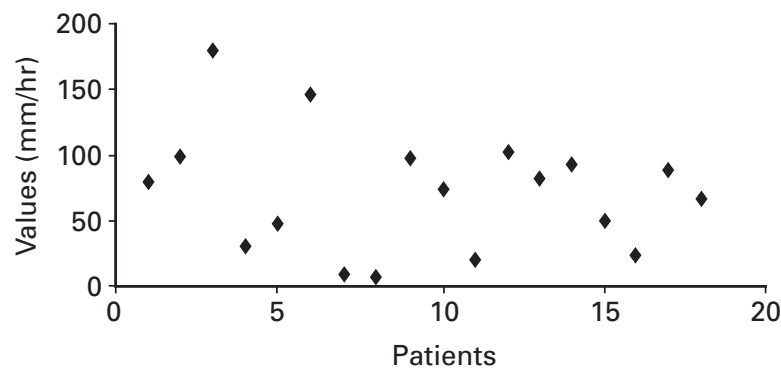

Fig. 1

The pre-operative values for the ESR in the 17 patients.

bone ends are debrided and if necessary minimally resected. Adjacent cortical surfaces are 'petalled' as described by Colchero, Orst and Videal ${ }^{33}$ to ensure viability. Multiple specimens are taken for aerobic and anaerobic microbiological culture and histology. The medullary canal is then reamed to remove debris and prepared for the insertion of the irrigation tubes. The usual approach for proximal entry for reaming is used in both the tibia and femur. The distal portal for retrograde reaming and placement of the irrigation tube in the femur is in the lateral femoral condyle, usually posterior enough to avoid any subsequent problem with future fixation of an implant. Similarly, in the tibia the distal portal is placed anteromedially. In both the femur and tibia an oblique approach to the canal is made and the bony track elongated to allow the tube to sit flat against the bone. Sequential reaming is performed, both antegrade and retrograde, using flexible reamers of up to $13 \mathrm{~mm}$ where possible for thorough debridement of infected endosteum and to allow space for two $6 \mathrm{~mm}$ tubes. More extensive reaming may be indicated for the removal of necrotic tissue. Specimens are taken for microbiology and the canal is intermittently irrigated to prevent thermal injury. At the end of reaming, the medullary canal is irrigated with 9 to 12 litres of normal saline at body temperature using a pulsed lavage system. The effluent is collected and checked to ensure that there has been elimination of particulate debris. Two double-lumen $6 \mathrm{~mm}$ tubes are inserted one into either end of the bone traversing the whole length of the canal. The outer tube, a large suction drain, is perforated at intervals and is used to drain effluent and measure cavity volumes. The inner tube, a central venous line, is used to deliver antibiotics. The complete arrangement is shown in Figure 2.

Dye studies have demonstrated that this system is capable of providing a continuous circulation of fluid within the medullary cavity. If there has been extensive soft-tissue infection and dissection, a third tube is laid outside the bone. The tubes are carefully secured to the skin with sutures. The soft tissues are closed in a single layer using nylon sutures. Closed suction drains are used when necessary. An above-knee plaster is applied to immobilise joints and prevent unnecessary movement. Where additional support is required in the femur traction may also be necessary. 


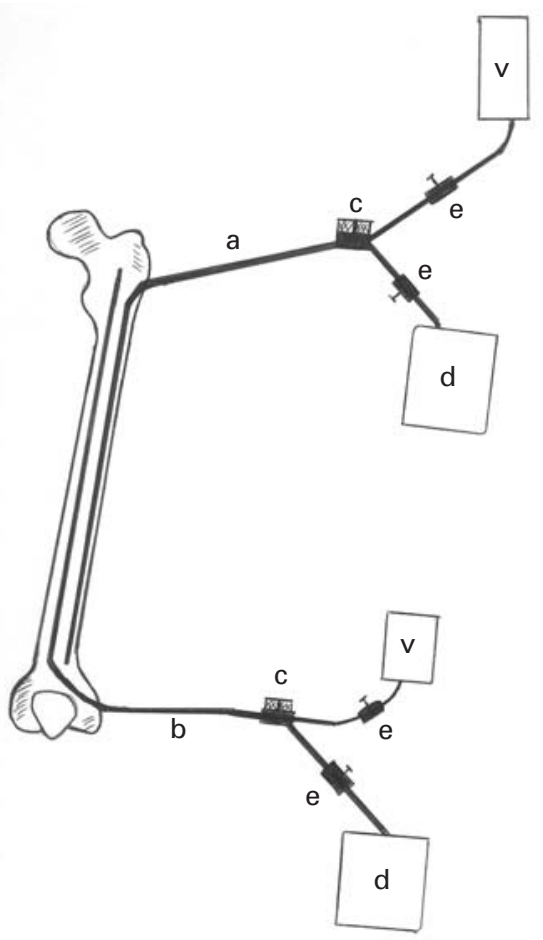

Fig. 2

Diagram showing the Lautenbach suystem ( $a$ and $b$, proximal and distal double-lumen tubes; $c$, junction of fine tube with outer tube; d, drain bags; e, valves; $v$, antibiotics in Varidase solution.

Further stabilisation, for example by external fixation, may be considered, but it may be technically difficult to achieve stable fixation without jeopardising the irrigation system or increasing the risk of infection. For these reasons it is avoided until the tubes are removed and soft tissues and wounds have healed.

After operation the cavity volume is measured by emptying the wound and canal by suction and then filling it until it overflows passively without pressure from the outlet. If the sensitivities are not known, a broad-spectrum antibiotic is started but is changed to the most effective narrow-spectrum single or combination of antibiotics as soon as sensitivities are available. Intravenous antibiotics are given for only 48 hours.

For local instillation the antibiotic is mixed with Varidase $^{34}$ in a $100 \mathrm{ml}$ bag of saline. The use of Varidase is important since it helps to prevent blockage of the tube. Chemical compatibility with the preferred antibiotics is always checked. Initially, 20 drops are allowed into tube; then 3.5 hours later the taps are opened to allow free drainage for 30 minutes. This cycle is repeated every four hours. At the end of every period of 12 hours the remaining solution is discarded. Every 24 hours the tube system is flushed through.

Samples are taken twice weekly for culture and sensitivity from the fluid drained passively at the end of each cycle. The antibiotics are altered if necessary. The irrigation fluid is inoculated directly on to two blood agar plates, which are incubated aerobically and anaerobically for 48 hours. In addition $1 \mathrm{ml}$ of the fluid is added to $80 \mathrm{ml}$ of Brain heart infusion broth and $20 \mathrm{ml}$ of 'Fastidious' anaerobic broth, which are inspected daily for signs of growth and subcultured at seven days on to two blood agar plates as above. Following advice from our senior clinical microbiologist, occasional isolates of less pathogenic organisms such as diptheroids, enterococci, coagulase-negative staphylococci and fungi were generally ignored, but repeated growths of gram-negative bacilli were treated with appropriate antibiotics, usually gentamicin, in the irrigation fluid. These less virulent organisms may have been the cause of osteomyelitis, or have contaminated the drainage system. With the Lautenbach procedure, once dead tissue is excised and replaced with healthy vascularised granulation and the dead space obliterated, these less virulent organisms are probably controlled by the body's own immune system.

Blood tests including a full blood count and measurement of the ESR, C-reactive protein and urea and electrolytes are performed weekly. If a toxic antibiotic is used its serum levels are also checked. The cavity volumes are measured weekly using the technique described above.

The principle is to ensure the local delivery of specific antibiotics at high concentration until the dead space is substituted by vascular tissue. This is reflected by the progressive reduction of the cavity volumes.

The tubes are removed when there have been three negative cultures of clear irrigated fluid, a zero or markedly reduced cavity volume and a downward trend of the inflammatory indices. The first tube is removed when the cavity volume is reduced to the volume of tubes and three consecutive culture results are negative. The second tube is removed when the cavity volume is reduced to the volume of one tube and further negative cultures are obtained.

The nursing and post-operative management have been described by Sims et al. ${ }^{35}$

\section{Results}

The details of the patients and the results are shown in Table II and the microbiological data in Table III. The mean duration of surgery was 5 hours (3 to 10). The mean blood transfusion was 3 units ( 0 to 8 ). Two patients needed skeletal traction and the remainder Plaster-of-Paris back slabs. Two patients had to be transferred to the high-dependency unit because of prolonged surgery and blood loss.

Intramedullary tubes were used in all cases. The first tube was removed at a mean of 22.2 days (14 to 48 ) and the second at 27.8 days (16 to 48 ). A third tube in the soft tissue was used in four patients and was removed at a mean of 28 days ( 24 to 30 ). A second tube in the soft-tissue space was used in three patients and removed at 32 days ( 24 to $38)$. The patients were mobilised at a mean of 2.6 weeks. The mean hospital stay was 38 days (26 to 78 ; median 37 ).

Complications encountered during treatment were pressure sores in one patient, local skin problems in three, dis- 
Table II. Details of the 17 patients with chronic osteomyelitis

\begin{tabular}{|c|c|c|c|c|c|c|c|c|c|c|c|c|c|}
\hline Case & $\begin{array}{l}\text { Age } \\
\text { (yrs) }\end{array}$ & Smoker & $\begin{array}{l}\text { Mechanism } \\
\text { of injury }\end{array}$ & Segment & $\begin{array}{l}\text { Fracture } \\
\text { status }\end{array}$ & $\begin{array}{l}\text { Previous } \\
\text { treatment* }\end{array}$ & $\begin{array}{l}\text { Years } \\
\text { from } \\
\text { injury }\end{array}$ & Fracture & Secondary surgery & Union & $\begin{array}{l}\text { Final/ } \\
\text { ESR } \\
\text { (ml/hr) }\end{array}$ & $\begin{array}{l}\text { Final } \\
\text { CRP } \\
\text { (mg/dl) }\end{array}$ & $\begin{array}{l}\text { Follow-up } \\
\text { (yrs) }\end{array}$ \\
\hline 1 & 40 & No & Gunshot & Femur & Open & ORIF & 19 & Nonunion & IMN for nonunion & Yes & 8 & 6 & 7 \\
\hline 2 & 33 & Yes & Motorcycle & Femur & Open & ORIF & 15 & United & $\begin{array}{l}\text { Leg lengthening, } \\
\text { Amputation }\end{array}$ & Yes & 12 & 7 & 6 \\
\hline 3 & 50 & Yes & Industrial & Tibia & Open & Exfix/IMN & 3 & United & $\mathrm{Nil}$ & Yes & 10 & 6 & 6 \\
\hline \multirow[t]{2}{*}{4} & 35 & Yes & RTAt & Tibia & Closed & ORIF & 15 & United & $\begin{array}{l}\text { Papineau/ } \\
\text { Lautenbach }\end{array}$ & Yes & 16 & 4 & 7 \\
\hline & 35 & Yes & RTA & Tibia & Closed & $\begin{array}{l}\text { ORIF/ } \\
\text { Lautenbach }\end{array}$ & 15 & United & Curettage and flap & Yes & 4 & 5 & 5 \\
\hline 5 & 41 & No & Motorcycle & Femur & Open & ORIF & 23 & Nonunion & $\mathrm{Nil}$ & Yes & 3 & 5 & 5 \\
\hline 6 & 41 & No & Motorcycle & Femur & Closed & IMN & 25 & United & Scope knee & Yes & 6 & 5 & 5 \\
\hline 7 & 17 & No & Sports cycle & Femur & Closed & Other & 1 & Nonunion & Nil & Yes & 2 & 5 & 6 \\
\hline 8 & 36 & Yes & Motorcycle & Femur & Closed & IMN & 19 & United & $\begin{array}{l}\text { Leg lengthening, } \\
\text { scope ankle }\end{array}$ & Yes & 4 & 5 & 6 \\
\hline 9 & 53 & Yes & Motorcycle & Femur & Open & IMN & 31 & United & Total hip replacement & Yes & 7 & 6 & 6 \\
\hline 10 & 37 & Yes & Motorcycle & Femur & Closed & IMN & 9 & Nonunion & $\begin{array}{l}\text { IMN for nonunion, } \\
15 \mathrm{~cm} \text { short, } \\
\text { Amputation }\end{array}$ & No & 25 & 13 & 4 \\
\hline 11 & 22 & Yes & RTA & Tibia & Open & ExFix & 1 & United & IMN for malunion & Yes & 11 & 6 & 6 \\
\hline 12 & 33 & No & Sports & Tibia & Closed & ORIF & 3 & Nonunion & Ext Fix malunion & Yes & 10 & 6 & 7 \\
\hline 13 & 47 & Yes & Motorcycle & Tibia & Open & ORIF & 21 & Nonunion & Papineau & Yes & 8 & 6 & 5 \\
\hline 14 & 38 & No & Pedestrian & Femur & Open & ORIF & 3 & Nonunion & $\begin{array}{l}\text { Ext Fix nonunion, } \\
\text { leg lengthening }\end{array}$ & Yes & 10 & 5 & 6 \\
\hline 15 & 24 & Yes & Motorcycle & Tibia & Open & IMN & 2 & Nonunion & $\begin{array}{l}\text { Ext Fix nonunion, } \\
\text { leg lengthening }\end{array}$ & Yes & 11 & 9 & 6 \\
\hline 16 & 50 & Yes & Industrial & Tibia & Open & IMN & 5 & Nonunion & Ext Fix nonunion & Yes & 5 & 5 & 6 \\
\hline 17 & 37 & No & Motorcycle & Tibia & Open & ExFix & 20 & United & Ankle arth deb & Yes & 5 & 5 & 5 \\
\hline
\end{tabular}

* ORIF, Open reduction and internal fixation; IMN, intramedullary nail; ExFix, external fixation

$\dagger$ road-traffic accident

Table III. Microbiological findings for the 17 patients

\begin{tabular}{|c|c|c|c|c|c|c|}
\hline Case & Primary Organism (1) & Intramed antibiotics & Antibiotic 1 Oral/IV & Secondary organism & $\begin{array}{l}\text { Intramed } \\
\text { antibiotics (2) }\end{array}$ & $\begin{array}{l}\text { Antobiotic } 2 \\
\text { Oral/IV }\end{array}$ \\
\hline 1 & Staph. aureus & Flucloxacillin & Flucloxacillin & Pseudomonas aeruginosa & Gentamicin & Flucloxacillin \\
\hline 2 & Staph. aureus & Flucloxacillin & Flucloxacillin & Nil & Nil & Nil \\
\hline 3 & Staph. aureus & Flucloxacillin & Flucloxacillin & Anaerobes & Gentamicin & Flucloxacillin \\
\hline \multirow[t]{2}{*}{4} & $\begin{array}{l}\text { Staph. aureus, } \\
\text { Bacteroids, } \\
\text { Diphtheroid }\end{array}$ & $\begin{array}{l}\text { Flucloxacillin, } \\
\text { gentamicin }\end{array}$ & Flucloxacillin & Anaerobes & $\begin{array}{l}\text { Gentamicin, } \\
\text { metron }\end{array}$ & \\
\hline & $\begin{array}{l}\text { Staph. coag-negative } \\
\text { entrobacteriaceae }\end{array}$ & Metron, gentamicin & Cefuroxime & Nil & Nil & Nil \\
\hline 5 & $\begin{array}{l}\text { Staph. aureus, } \\
\text { coag-neg staph. }\end{array}$ & Flucloxacillin & Flucloxacillin & Nil & Nil & Nil \\
\hline 6 & Staph. aurerus & Flucloxacillin & Flucloxacillin & Nil & Nil & Nil \\
\hline 7 & Staph. aurerus & Flucloxacillin & Flucloxacillin, Fucidin & Nil & Nil & Nil \\
\hline 8 & Staph. aurerus & Flucloxacillin & Flucloxacillin & Nil & Nil & Nil \\
\hline 9 & Pseudomonas aeruginosa & Gentamicin & Gentamicin IV & $\begin{array}{l}\text { Staph coag-neg and } \\
\text { Diphtheroids }\end{array}$ & $\begin{array}{l}\text { Vancomicin/ } \\
\text { Flucloxacillin }\end{array}$ & Nil \\
\hline 10 & Staph coag-negative & Flucloxacillin & Flucloxacillin & Diphtheroids & Gentamicin & Nil \\
\hline 11 & Staph. coag-negative & Flucloxacillin & Flucloxacillin & Nil & Nil & Nil \\
\hline 12 & Staph. Aureus & Flucloxacillin & Flucloxacillin & Nil & Nil & Nil \\
\hline 13 & $\mathrm{MRSA}^{*}$ & Vancomycin & Fucidin, IV gentamycin & Nil & Nil & Nil \\
\hline 14 & $\begin{array}{l}\text { Proteus mirabilis, } \\
\text { Peptostrep sp }\end{array}$ & $\begin{array}{l}\text { Flucloxacillin, } \\
\text { gentamicin }\end{array}$ & Fucidin, Gentamicin & Nil & Nil & $\mathrm{Nil}$ \\
\hline 15 & Staph. aureus & Flucloxacillin & Flucloxacillin & $\begin{array}{l}\text { Straptococcus, pygenes, } \\
\text { Diphtheroids }\end{array}$ & Gentamicin & Ciprofloxacin \\
\hline 16 & Staph. aureus & Flucloxacillin/Fucidin & Flucloxacillin & Nil & Nil & Nil \\
\hline 17 & Pseudomonas aeruginosa & Gentamicin & Ciprofloxacin, amoxicillin & Nil & Nil & Nil \\
\hline
\end{tabular}

* methicillin-resistant Staph. aureus 


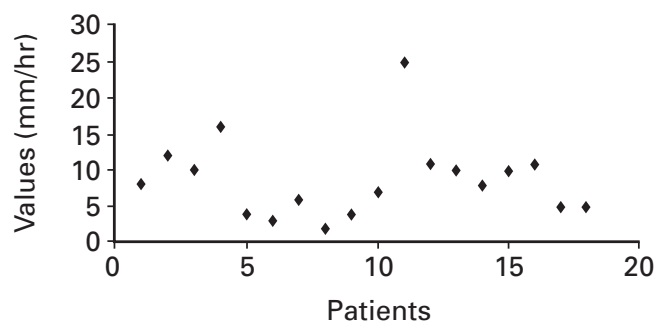

Fig. 3a

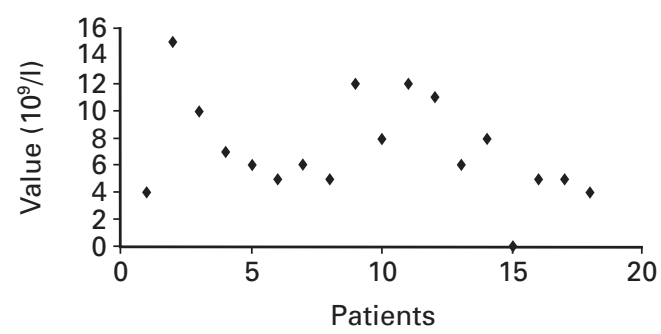

Fig. 3c

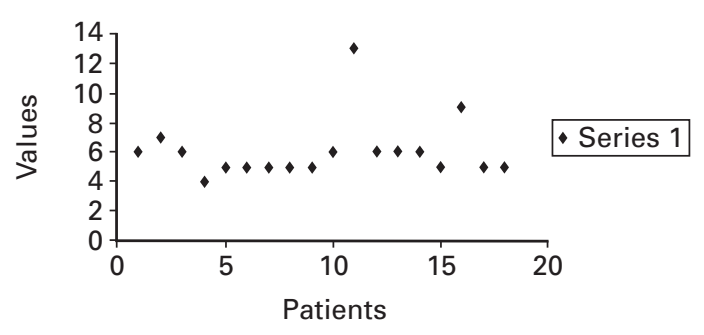

Fig. 3b

Blood indices at the last review showing a) the ESR, b) $\mathrm{C}$-reactive protein and c) the white cell count.
Table IV. Blood indices at the last review

\begin{tabular}{lccr}
\hline Test & Mean & Median & Range \\
\hline White cell count $\left(10^{9} / \mathrm{l}\right)$ & 6.8 & 6.0 & 4 to 12 \\
ESR $(\mathrm{mm} / \mathrm{hr})$ & 8.22 & 7.0 & 3 to 25 \\
C-reactive protein $(\mathrm{mg} / \mathrm{dl})$ & 6.0 & 5.0 & 5 to 13 \\
Haemoglobin $(\mathrm{g} / \mathrm{dl})$ & 13.8 & 14.5 & 10 to 16 \\
\hline
\end{tabular}

lodgement of a tube in one, an abscess at the site of a tube in one, wound leakage in one, a local haematoma in one and pulmonary embolism in another.

When we were confident that the infection had been cured, some patients had further operations including multifocal limb lengthening, correction of deformity and total hip replacement.

Healing was achieved in eight of the nine fractures which had not previously united. There was one recurrent infection (case 4), which was cured with a repeat Lautenbach procedure. This patient underwent Papineau grafting, ${ }^{22,23}$ local curettage and a muscle flap with a split-skin graft.

Two patients required below-knee amputation despute eradication of the infection. The first (case 10) had $15 \mathrm{~cm}$ of shortening with a nonunion. He remained free from infection and had an amputation 19 months after the Lautenbach procedure. The second patient (case 2) had failure of a limb lengthening with an insensate foot.

The mean follow-up was for 75 months (56 to 95; median 78). The blood indices at the last review are shown in Table IV and Figure 3.

\section{Discussion}

The management of chronic osteomyelitis is complicated by the presence of dead bone in a scarred soft-tissue envelope with a poor blood supply. ${ }^{8}$
The criteria for treatment of chronic osteomyelitis include adequate debridement of necrotic, infected soft tissue and osseous structures; ${ }^{26,31,36,37}$ the preservation or creation of bony stability; ${ }^{13}$ the ablation of dead space by packing and change of dressings, the use of methylmethacrylate, bone graft, closed suction irrigation, or muscle insertion; ${ }^{10,13,38,39}$ adequate antibiotic therapy; ${ }^{31,38}$ and appropriate soft-tissue cover. ${ }^{10,14}$

After debridement of soft tissue and bone a potential dead space is formed in which haematomas may collect. ${ }^{40}$ Several approaches have been described to reduce the dead space including open ${ }^{22,23}$ or closed bone grafting, ${ }^{4}$ a local or free muscle flap ${ }^{14}$ and closed wound irrigation with suction. ${ }^{15,16,20,40}$

The concept of wound irrigation in the management of chronic osteomyelitis dates back at least to $1917 .{ }^{41} \mathrm{In}$ 1945 Smith-Petersen et a ${ }^{20}$ described local chemotherapy with primary wound closure. This idea was further propagated by Goldman et al, ${ }^{17}$ McElvenny, ${ }^{19}$ Compere et al ${ }^{16}$ and Kelly et al. ${ }^{18}$ All these authors 'saucerised' the infected area and assembled an irrigation system in the soft tissue adjacent to the saucerised bone. The intramedullary procedure of Weber and Lautenbach ${ }^{21}$ has been used for infected total hip arthroplasties, but also for pandiaphyseal chronic osteomyelitis. This technique leaves the surgeon with precise control over the local environment of the wound. It allows close monitoring of changes in the bacterial flora and their sensitivities, which in turn enables delivery of high doses of specific antibiotics to be made into the medullary canal without systemic toxic effects. ${ }^{42,43}$ The cavity of the dead space is replaced by healthy vascular granulation tissue. An analysis of the published results of the closed irrigation/delivery systems is given in Table $\mathrm{V}^{44}$ 
Table V. Details of published results of closed irrigation/antibiotic delivery systems

\begin{tabular}{|c|c|c|c|c|}
\hline Authors & $\begin{array}{l}\text { No. of } \\
\text { patients }\end{array}$ & $\begin{array}{l}\text { Duration of } \\
\text { infection }\end{array}$ & Success (\%) & $\begin{array}{l}\text { Mean } \\
\text { follow-up } \\
\text { (mths) }\end{array}$ \\
\hline Compere et al ${ }^{16}$ & 21 & & $52.0(71.4)^{*}$ & 30.0 \\
\hline Kelly et al ${ }^{18}$ & 40 & 68.7 mths & 72.0 & 28.25 \\
\hline Clawson et $\mathrm{al}^{15}$ & 97 & 26.4 mths & 73.0 & 16.0 \\
\hline Weber and Lautenbach 21 & 33 & & 88.0 & 72.0 \\
\hline Perry et al ${ }^{43}$ & 21 & & 72.0 & 27.0 \\
\hline Koval et $\mathrm{al}^{6}$ & 11 & & $27.0(45.5)^{*}$ & 65.0 \\
\hline Meani and Romano ${ }^{42}$ & 10 & 1 to 15 yrs & 88.8 & 33.7 \\
\hline
\end{tabular}

* shows final result after revision surgery

Table VI. Published results after debridement, stabilisation and management of the cavity

\begin{tabular}{lcll}
\hline Author/s & $\begin{array}{l}\text { No. of } \\
\text { patients }\end{array}$ & Success (\%) & $\begin{array}{l}\text { Mean follow-up } \\
\text { (mths) }\end{array}$ \\
\hline Koval et al $^{6}$ & 15 & $60 \quad 80^{*}$ & 48 \\
McNally et al $^{14}$ & 37 & 91 & 49 \\
Swiontkowski et al $^{9}$ & 93 & 91 & 31 \\
Cierny $^{53}$ & 101 & 93 & 60 \\
\hline
\end{tabular}

* shows final result after revision surgery

Management of the dead space after debridement using antibiotic-impregnated beads was popularised by Bucholz in the early $1970 \mathrm{~s} .{ }^{45}$ Walenkamp et al ${ }^{44}$ described a series of 100 patients treated with gentamicin-polymethylmethacrylate beads, with a mean follow-up of five years and a success rate of $78 \%$ with a single treatment period comprising one to five operations. Cierny ${ }^{32}$ described the use of customised antibiotic beads as the main tool for management of the dead space with an overall success rate of $92 \%$, but with this technique the antibiotic could not be adjusted to changing sensitivities of the flora. Lautenbach ${ }^{46}$ compared, $^{2}$ prospectively, his technique with gentamicin beads and found that the results were better with a recurrence of $25 \%$ at the first treatment compared with that of $40 \%$ using beads.

Debridement, stabilisation and management of the cavity using bone graft and a flap have also shown good results (Table VI). Koval et $\mathrm{al}^{6}$ achieved a success rate of $60 \%$ with primary debridement and flap cover, and their results improved to $80 \%$ after further operations. The 'Belfast technique' described by McNally et $\mathrm{al}^{14}$ comprises a two-staged procedure. A radical debridement with softtissue cover constituted the first stage, and in some cases gentamicin-impregnated beads were used. The second stage involved the use of an autogenous bone graft. There was a recurrent deep infection in $13 \%$ of patients and $10 \%$ had problems with the wound needing further surgery. The overall success rate was $91 \%$.

Swiontkowski et $\mathrm{al}^{9}$ reported 93 patients who had had a single-stage aggressive surgical debridement with softtissue cover. In this group $41 \%$ needed antibiotic-impregnated beads, which were subsequently removed, $37 \%$ received a delayed autologous bone graft and 33\% had a free tissue transfer.

Ilizarov introduced the concept that "osteomyelitis burns in the fire of regenerate", but Catagni's ${ }^{48}$ experience has shown that although bone healing was achieved, infection was not always eliminated, with residual infection in $17.5 \%$. He strongly advocated open debridement and enbloc excision as a bifocal procedure. ${ }^{48,49}$ The mean time in a frame was nine months. Saleh and Rees ${ }^{50}$ employing bifocal surgery experienced a mean time of treatment of 16 months for bone transport and a cure of infection of $100 \%$.

Marsh et $\mathrm{al}^{51}$ described 22 patients with osteomyelitis, including 20 with nonunion, treated by the Ilizarov method with segmental excision and distraction osteogenesis. In this series three fractures failed to heal with the primary procedure and one patient needed a free flap. He reported complete cure of infection at a mean follow-up of 23 months. Ekkernkamp, Muhr and Josten ${ }^{52}$ have shown elimination of infection in $94 \%$ of 71 patients.

The Ilizarov technique using en-bloc excision and transport has given excellent results but it needs a specialist team with a multidisciplinary approach and usually prolonged treatment time. ${ }^{48,49}$

The patients in our series had established chronic osteomyelitis, and all had previous failed operations with wound debridement and antibiotics. Using the Lautenbach technique, we achieved a success rate of $94.4 \%$ with the primary procedure. All these patients remained free from infection. Two had amputations after the infection had been eradicated for other reasons.

The procedure is indicated for complex cases of osteomyelitis in which conventional surgical debridement and systemic antibiotics have failed.

The authors would like to thank Dr A. Ali and M. Simms, Nurse Specialist.

No benefits in any form have been received or will be received from a commercial party related directly or indirectly to the subject of this article.

\section{References}

1. Simpson AHRW, Deakin M, Latham JM. Chronic osteomyelitis: the effect of the extent of surgical resection on infection-free survival. J Bone Joint Surg [Br] 2001; 83-B:403-7.

2. Cabanela ME. Open cancellous bone grafting of infected bone defects. 49th annual meeting of the American Academy of Orthopaedic Surgeons, 1982.

3. Malkawi H, Shannak A, Sunna P. Active treatment of segmental defects of long bones with established infection: a prospective study. Clin Orthop 1984;184:241-8.

4. Oliveria JC. Bone graft and chronic osteomyelitis. J Bone Joint Surg [Br] 1971;53-B: 672-83.

5. Zinberg EM. Free muscle transfer for chronic osteomyelitis. Surg Rounds 1989; March:26-32.

6. Koval KJ, Meadows SE, Rosen H, Silver L, Zuderman JD. Post-traumatic tibial osteomyelitis: a comparison of three treatment approaches. Orthop 1992;15:455-60.

7. Haas DW, McAndrew MP. Bacterial osteomyelitis in adults: evolving considerations in diagnosis and treatment. Am J Med 1996;101:550-61.

8. Cierny G, Mader JT. Adult chronic osteomyelitis. Orthop Oct 1984; Vol 7, No 10: 1557-64.

9. Swiontkowski MF, Hanel DP, Vedder NB, Schwappach JR. A comparison of short- and long-term intravenous antibiotic therapy in the postoperative management of adult ostemyelitis. J Bone Joint Surg [Br] 1999;81-B:1046-50.

10. Fitzgerald RH. The epidemiology of nosocomial infections of the musculoskeletal system. Hospital associated infections in the General Hospital population and specific measures of control. New York: NY Dekker, 1979;3:25-35. 
11. Klemm KW. Treatment of infected pseudoarthrosis of the femur and tibia with an interlocking nail. Clin Orthop 1986;212:174-81.

12. O'Riordan C, Adler JL, Banks HH, Finland M. Wound infection on an orthopaedic service: a prospective study. Am J Epidemio/ 1972;95:442-50.

13. Myers S, Weiland AJ, Willenegger $\mathbf{H}$. The treatment of infected non-union of fracture of long bones: study of 64 cases with a five to twenty-one-year follow-up. J Bone Joint Surg [Am] 1975;57-A:836-42.

14. McNally MA, Small Jo, Tofighi HG, Mollan RAB. Two-stage management of chronic osteomyelitis of the long bones: the Belfast technique. J Bone Joint Surg [Br] 1993;75-B:375-80

15. Clawson DK, Davis FJ, Hansen ST Jr. Treatment of chronic osteomyelitis with emphasis on closed suction-irrigation technic. Clin Orthop 1973;96:88-97.

16. Compere EL, Metzger WI, Mitra RN. Treatment of pyogenic bone and joint infection by closed irrigation (Circulation) with a non-toxic detergent and one or more antibiotics. J Bone Joint Surg [Am]1967;49-A:614-24.

17. Goldman MA, Johnson RK, Grossberg NM. A new approach to chronic osteomyelitis. Am J Orthop 1960;2:63-65.

18. Kelly PJ, William WJ, Coventry MB. Chronic osteomyelitis II: treatment with closed irrigation and suction. JAMA 1970;213:1843-8.

19. McElvenny RT. The use of closed circulation and suction in the treatment of chronically infected, acutely infected and potentially infected wounds. Am J Orthop 1961;3: 86.3:154-9.

20. Smith-Petersen MN, Larson CB, Williams C. Local chemotherapy with primary closure of septic wounds by means of drainage and irrigation cannulae. J Bone Joint Surg 1945;27:562-71.

21. Weber FA, Lautenbach EEG. Revision of infected total hip arthroplasty. Clin Orthop 1986;211:108-15

22. Papineau LJ. Excision-graft with deliberately delayed closing in chronic osteomyelitis. Nouv Presse Med 1973;2:2753-55

23. Papineau LJ, Allfageme A, Dalcourt JP, Pilon L. Chronic osteomyelitis: open excision and grafting after saucerisation. Int Orthop 1979;3:165-76.

24. Rhinelander FW. Minimal internal fixation of tibial fractures. Clin Orthop 1975;107: 188-220.

25. Rhinelander FW. Tibial blood supply in relation to fracture healing. Clin Orthop 1974; 105:34-41

26. Sachs BL, Shaffer JW. A staged Papineau protocol for chronic osteomyelitis. Clin Orthop 1984;184:256-63.

27. Saleh M, Kreibich ND, Ribbans WJ. Circular frames in management of infected tibial non-union: a modification of Papineau technique. Injury 1996;27:31-3.

28. Saleh M. Nonunion surgery part 1: basic principles of management. Int J Orthop Trauma 1992;2:4-18.

29. Fitzgerald RH Jr, Ruttle PE, Arnold PG, Kelly PJ, Irons GB. Local muscle flaps in treatment of chronic osteomyelitis. J Bone Joint Surg [Am] 1985;67-A:175-85.

30. Mathes SJ, Alpert BS, Chang N. Use of muscle flap in chronic osteomyelitis: experimental and clinical correlation. Plast Reconstr Surg 1982;69:815-25.
31. Weiland AJ, Moore RM, Daniel RK. The efficacy of free tissue transfer on the treatment of osteomyelitis. J Bone Joint Surg [Am] 1984; 66-A:181-93.

32. Cierny G 3rd. Chronic osteomyelitis: results of treatment. Inst Course Lect 1990;39: 495-508.

33. Colchero FR, Orst G, Videal J. Scarification: its role in the treatment of chronic postulated pyogenic osteoarticular infection. Int Orthop 1982;6:263-71.

34. Varidase. British national formulary, section 13.11 Vol. 46, 2003.

35. Sims M, Trent JC, Hashmi MA, Saleh M. The Lautenbach method for chronic osteomyelitis: nursing roles, responsibilities and challenges. J Orthop Nursing 2000; 5:198-205.

36. Shannon JG, Woolhouse FM, Eisinger PJ. The treatment of chronic osteomyelitis by saucerization and immidiate skin graft. Clin Orthop 1973;96:98-107.

37. Tetsworth K, Cierney G 3rd. Osteomyelitis debridement techniques. Clin Orthop 1999;360:87-96.

38. Rosen H. Operative treatment of nonunion of long bone fractures. J C E Orthop 1979 98-107.

39. Cierney G, Mader JT. Approach to adult osteomyelitis. Orthop Rev1987;16:95-106

40. Kelly PJ, Martin WJ, Coventry MB. Chronic osteomyelitis II: treatment with closed irrigation and suction. J A M A Sept 14 1970;Vol 213,11:1843-8.

41. Dumas J, Carrel A. Pratique de l'irrigation des plaies. Paris, Maloine, 1917.

42. Meani E. Romano C. Treatment of osteomyelitis by local antibioticsusing portable electronic pump. Rev Chir Orthop Reparatrice Appar Mot 1994;80:285-90.

43. Perry CR, Davenport K, Vossen MK. Local delivery of antibiotics via an implantable pump in treatment of osteomyelitis. Clin Orthop 1988;226:222-30.

44. Walenkamp GHIM, Kleija LL, de Leeuw M. Osteomyelitis treated with gentamycinPMMA beads: 100 patients followed for 1-12 years. Acta Orthop Scand 1998:69:518-22

45. Buchholz HW, Engelbrecht H. Uber die Depotwirkung einiger Antibiotika bei Vermischung mit dem Kunstharz Palacos. Chirurgn 1970; 40:511-5.

46. Lautenbach EEG. The treatment of bone infection with PMMA beads compared with local antibiotic instillation. J Bone Joint Surg [Br] 1980;62-B:275.

47. Calhoun JH, Mader JT. Treatment of osteomyelitis with a biodegradable antibiotic implant. Clin Orthop 1997;341:206-14.

48. Catagni MA. Treatment of infected nonunions. Treatment of fracture nonunions and bone loss of tibia with the llizarov method. 143-58.

49. Cattaneo R, Catagni M, Johnson EE. The treatment of infected non-unions and segmental defects of the tibia by the methods of Ilizarov. Clin Orthop 1992;280:143-52.

50. Saleh M, Rees A. Bifocal surgery for deformity and bone loss after lower limb fractures. J Bone Joint Surg [Br] 1995;77-B:429-34.

51. Marsh DR, Shah S, Elliott J, Kurdy N. The llizarov methods in nonunion, malunion and infection of fractures. J Bone Joint Surg [Br] 1997;79-B:273-9.

52. Ekkernkamp A, Muhr G, Josten C. Infected pseudarthrosis. Unfallchirurg 1996;99: 914-24.

53. Cierny G 3rd. Infected tibial nonunions: the evolution of change. Clin Orthop 1999; 360:97-105 